\title{
SYNTHESIS AND SPECTRAL CHARACTERIZATION OF SCHIFF BASE TRANSITION METAL COMPLEXES, DNA CLEAVAGE AND ANTIBACTERIAL ACTIVITY STUDIES
}

\author{
M. Vijayalakshmi \\ Nandha Engineering College, Erode-638052, Tamilnadu \\ E-mail: viji.deepu2008@yahoo.co.in
}

\begin{abstract}
A new string of transitional metal complexes of $\mathrm{Cu}(\mathrm{II}), \mathrm{Zn}(\mathrm{II})$ and $\mathrm{Ni}(\mathrm{II})$ have been synthesized from the Schiff base ligand derived from 2,4-dihydroxybenzaldehyde and p-aminobenzoic acid. Structural studies were obtained by their elemental analysis, magnetic susceptibility, molar conductance, IR, UV-Visible, ${ }^{1} \mathrm{H}-\mathrm{NMR}$ and ESR spectral studies. The data shows that the complexes have a composition of ML type. The UV-Visible, magnetic susceptibility and ESR spectral data of the complexes proposed square planar geometry about the metal ion except for zinc complex. The redox behavior of the complexes was studied by cyclic voltammetry. An antimicrobial screening test shows good results in the presence of metal ion than in the ligand.

Keywords: Schiff base, 2,4-dihyroxybenzaldehyde, p-aminobenzoic acid, Antimicrobial activity, DNA cleavage
\end{abstract}

(C) RASĀYAN. All rights reserved

\section{INTRODUCTION}

The pasture of Schiff base complexes was the first budding version of the broad multiplicity of potential structures for the ligands depending upon the aldehyde and amines. Transition metal ions are vital to countless biological systems in natural history ${ }^{1}$. Metal ions are concerned in a large no of chemical reactions by the good feature of their capability to harmonize to simple or polymeric donor groups. The compounds have much curiosity because they habitually crop up in natural products and are organically important ${ }^{2}$. They have many applications both in the qualitative and quantitative analysis ${ }^{3,4}$. A tiny work has been carried out on the complexing performance of Schiff bases derived from 2,4dihydroxybenzaldehyde and P-Aminobenzoic acid with a variety of metal ions. The antibacterial behavior exposes that the metal complexes can be dynamic in opposition to the elected bacterial strains. Virtually, all of the compounds may ensemble glowing for drug rescue playing field past inspection of their toxicology deeds in a meticulous manner and show admirable catalytic commotion in an assortment of chemical reactions. DNA cleavage studies of metal complexes showed further high-flying action in the existence of $\mathrm{H}_{2} \mathrm{O}_{2}$ compared to that in the deficiency of $\mathrm{H}_{2} \mathrm{O}_{2}$. The ability of transition metal complexes to cleave nucleic acids efficiently with a high level of selectivity for a sit or sequence offers many applications for the manipulation of genes and development of novel therapeutics.

\section{EXPERIMENTAL}

All the chemicals 2,4-dihydroxy benzaldehyde, p-aminobenzoic acid and metal salts [acetate of $\mathrm{Cu}(\mathrm{II})$, $\mathrm{Ni}$ (II) and $\mathrm{Zn}(\mathrm{II})]$ used in the modern work were of analytical grade. The solvents like ethanol, methanol, DMSO, DMF etc were purified by ordinary methods.

\section{Physical Measurements}

UV-Visible absorption spectra study was measured on Hewlett Packard 8425A spectrometer. Elemental analysis was performed on an elemental vario EL 111 Carlo Erba 1108 analyzer. Molar conductance measurement was conducted using $10^{-3} \mathrm{M}$ solutions of the complexes in DMF on Elico - CM82 Conductivity Bridge at room temperature. Magnetic susceptibility measurement was carried out on a 
Gouy balance at room temperature. FT-IR spectra study was recorded in $\mathrm{KBr}$ medium on a Perkin Elmer RXI spectrophotometer in wave number region $4000-400 \mathrm{~cm}^{-1}$

\section{Synthesis of Schiff Base Ligands}

The preliminary material was prepared according to the literature survey ${ }^{5}$. An ethanolic solution of newly prepared 2,4-dihyroxybenzaldehyde was mixed with gradually stirring ethanolic solution of $p$ aminobenzoic acid. The mixture was refluxed at $70^{\circ} \mathrm{C}$ for $2 \mathrm{hr}$. On cooling yellow colored precipitate was alienated out, filtered, washed with ethanol and dried in vacuum ${ }^{6}$.The Schiff base ligand is shown in figure 1. Yield 70\% Elemental analysis: $\mathrm{C}_{14} \mathrm{H}_{11} \mathrm{NO}_{4}$, Calculated C-65.36\%, H-4.28\%, N-5.44\% ; Found $\mathrm{C}-65.33 \%, \mathrm{H}-4.25 \%, \mathrm{~N}-5.42 \% \quad v(\mathrm{C}=\mathrm{N}), 1619 \mathrm{~cm}^{-1}, v(\mathrm{C}=\mathrm{C}), 1542 \mathrm{~cm}^{-1}$, UV Vis $\left(\Lambda_{\max }\right), \mathrm{DMF} \pi \rightarrow \pi^{*}-$ $274 \mathrm{~nm}, \mathrm{n} \rightarrow \pi^{*}-315 \mathrm{~nm}$.

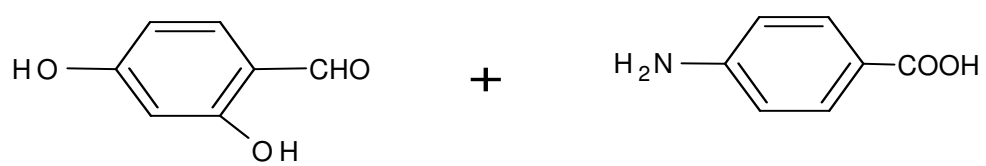

2,4-dihydroxy benzaldehyde

Reflux for 2 hrs

\section{Synthesis of Complexes}

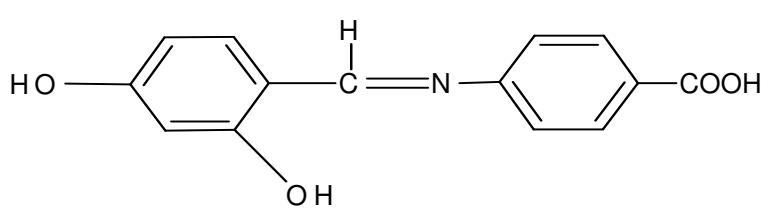

Fig.-1: Synthesis of Schiff base Ligand (L)

The various complexes were prepared by addition of $5 \mathrm{mM}$ of $\mathrm{Cu}\left(\mathrm{CH}_{3} \mathrm{COO}\right)_{2} \mathrm{H}_{2} \mathrm{O}, \mathrm{Zn}\left(\mathrm{CH}_{3} \mathrm{COO}\right)_{2} \mathrm{H}_{2} \mathrm{O}$ and $\mathrm{Ni}\left(\mathrm{CH}_{3} \mathrm{COO}\right)_{2} \mathrm{H}_{2} \mathrm{O}$ which were dissolved in about $20-30 \mathrm{ml}$ of deionized distilled water, were dissolved in about $20-30 \mathrm{ml}$ of water, into a hot methanolic solution of $5 \mathrm{mM}$ of the ligand (1:1) molar ratio. The color of the complexes changes in a few minutes. The mixture was then refluxed for 2 hrs. The precipitated solids were filtered and washed with methanol and followed by drying at $50^{\circ} \mathrm{C}$ overnight ${ }^{7}$. The Schiff base complexes were shown in Fig.-2.

\section{Cu(II) Complex}

Yield 64\% Elemental Analysis: $\mathrm{C}_{28} \mathrm{H}_{20} \mathrm{~N}_{2} \mathrm{O}_{8} \mathrm{Cu}$ Caculated C-58.33\%, H-3.47\%, N- $4.86 \%$, Cu $11.11 \%$; Found C-58.30\%, H-3.45\%, N-4.85\% Cu $11.12 \%, \Lambda_{\mathrm{m}}-15.25\left(\mathrm{ohm}^{-1} \mathrm{~cm}^{2} \mathrm{~mol}^{-1}\right), v(\mathrm{C}=\mathrm{N}), 1594 \mathrm{~cm}^{-1}, v$ $(\mathrm{M}-\mathrm{N})-456 \mathrm{~cm}^{-1}, v(\mathrm{M}-\mathrm{O}), 514 \mathrm{~cm}^{-1}, \mathrm{UV}$ Vis $\left(\Lambda_{\max }\right), \mathrm{DMF}: \mathrm{d} \rightarrow \mathrm{d} 614 \mathrm{~nm}$

\section{Zn(II) Complex}

Yield 60\% Elemental Analysis: $\mathrm{C}_{28} \mathrm{H}_{20} \mathrm{~N}_{2} \mathrm{O}_{8} \mathrm{Zn}$ Caculated C-58.23\%, H-3.46\%, N-4.85 \%, Zn=11.25\% ; Found C-58.25\%, H-3.44\%, N-4.85\%, Zn=11.26\%, $\Lambda_{\mathrm{m}}-13.56\left(\mathrm{ohm}^{-1} \mathrm{~cm}^{2} \mathrm{~mol}^{-1}\right), v(\mathrm{C}=\mathrm{N}), 1598 \mathrm{~cm}^{-1}, v$ $(\mathrm{M}-\mathrm{N})-478 \mathrm{~cm}^{-1}, v(\mathrm{M}-\mathrm{O}), 512 \mathrm{~cm}^{-1}, \mathrm{UV}$ Vis $\left(\Lambda_{\max }\right)$, DMF: $\mathrm{d} \rightarrow \mathrm{d}$ not observed

\section{$\mathrm{Ni}(\mathrm{II})$ Complex}

Yield 68\% Elemental Analysis: $\mathrm{C}_{28} \mathrm{H}_{20} \mathrm{~N}_{2} \mathrm{O}_{8} \mathrm{Ni}$ Caculated C-58.94\%, H-3.50\%, N-4.91 \%, Ni=10.17\% ; Found C-58.95\%, H-3.55\%, N-4.92\%, Ni=10.19\%, $\Lambda_{\mathrm{m}}-14.5\left(\mathrm{ohm}^{-1} \mathrm{~cm}^{2} \mathrm{~mol}^{-1}\right), v(\mathrm{C}=\mathrm{N}), 1590 \mathrm{~cm}^{-1}, v$ $(\mathrm{M}-\mathrm{N})-412 \mathrm{~cm}^{-1}, v(\mathrm{M}-\mathrm{O}), 513 \mathrm{~cm}^{-1}$ UV Vis $\left(\Lambda_{\max }\right), \mathrm{DMF}: \mathrm{d} \rightarrow \mathrm{d} 513,658 \mathrm{~nm}$

\section{RESULTS AND DISCUSSION}

The Schiff base complexes have been synthesized by condensation of Schiff base ligand with a metal salt solution. All the complexes were crystalline in character gloomy colored solid, stable at room temperature 
and soluble in DMF or DMSO. The ligand can be confirmed by ${ }^{1} \mathrm{H}-\mathrm{NMR}$. All the complexes gave agreeable elemental analysis outcome with the anticipated structure of the complexes. The creation and their geometry were further confirmed by IR, UV-Visible, magnetic, EPR spectral studies. The ligand and their metal complexes were also screened for antibacterial activity against bacteria species.

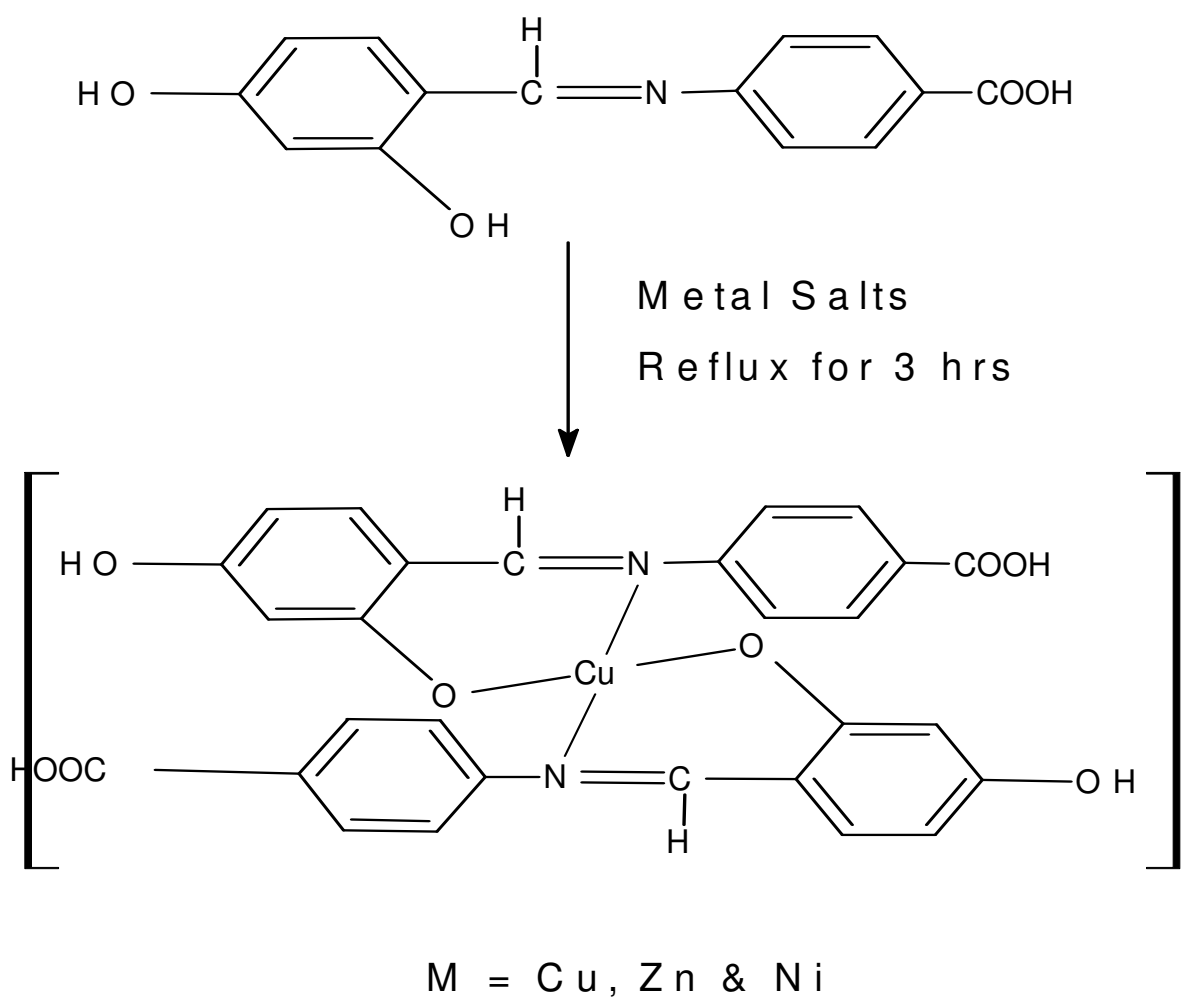

Fig.-2: Synthesis of Schiff base Complex derived from L

\section{${ }^{1}$ H-NMR Spectra of Schiff Base Ligand}

${ }^{1} \mathrm{H}-\mathrm{NMR}$ spectra of the compound were carried out in $\mathrm{d} 6$ - DMSO at room temperature using TMS as an internal standard. The Schiff base shows peaks at 7.0 and $7.1 \mathrm{ppm}$ which are attributable to the aromatic protons, peak at $13.6 \mathrm{ppm}$ which is attributable to the phenolic $\mathrm{OH}$ proton, while free azomethine proton was observed in the range of $8.51 \mathrm{ppm}$. The development of azomethine group in Schiff base was established by ${ }^{1} \mathrm{H}-\mathrm{NMR}$ spectrum as shown in Fig.-3.

\section{Electronic Absorption Spectra}

The electronic absorption spectra of the Schiff bases, $\mathrm{Cu}$ (II), Ni(II) and $\mathrm{Zn}$ (II) complexes were recorded at $300 \mathrm{k}$. The absorption region, assigned and the proposed geometry of the complexes are given in the Table-1. These values are comparable with that of the reported complexes ${ }^{8-11}$. Based resting on the exceeding factors, the planned structures of the Schiff base complexes are given in the Fig.- 4 and 5.

\section{Magnetic Properties}

The magnetic moments of the solid state complexes were measured at room temperature. The measured magnetic moments of mononuclear $\mathrm{Cu}(\mathrm{II})$ complex $1.70 \mathrm{BM}$. Magnetic susceptibility measurement showed that this complex is paramagnetic, which corresponds to the +2 oxidation state of $\mathrm{Cu}$ (II) complex. This indicates that $\mathrm{Cu}$ (II) complex ${ }^{12-13}$ exhibits square planar geometry. The $\mathrm{Ni}$ (II) complex has diamagnetic property using Gouy balance. The observed zero magnetic moment also confirms the square planar environment for the $\mathrm{Ni}$ (II) complex, it conventionality with the verity that all the known square 
RASĀYAN J. Chem.

Vol. 11 | No. 2 |857- 864 | April - June | 2018

planar complex of $\mathrm{Ni}(\mathrm{II})$ complex is diamagnetic ${ }^{12}$. The $\mathrm{Zn}(\mathrm{II})$ complex are diamagnetic having a $\mathrm{d}^{10}$ system which is tetrahedral as per anticipated

\section{EPR Spectral Studies}

The EPR spectra study was recorded at room temperature in DMF solution. The $\mathrm{Cu}(\mathrm{II}) \mathrm{Complex}$ provides one broad isotopic signal the free electron g-value (2.0023) pragmatic g-value is 2.1936.The lengthening of spectra most likely is due to spin relaxation ${ }^{14}$. In square planar complexes, the unpaired electron lies in the $\mathrm{d} \mathrm{x}^{2}-\mathrm{y}^{2}$ orbital giving $\mathrm{g}_{\|}>\mathrm{g}_{\perp}>2$. From the experimental value, the complex of square planar geometry is shown in Fig.- 6 .

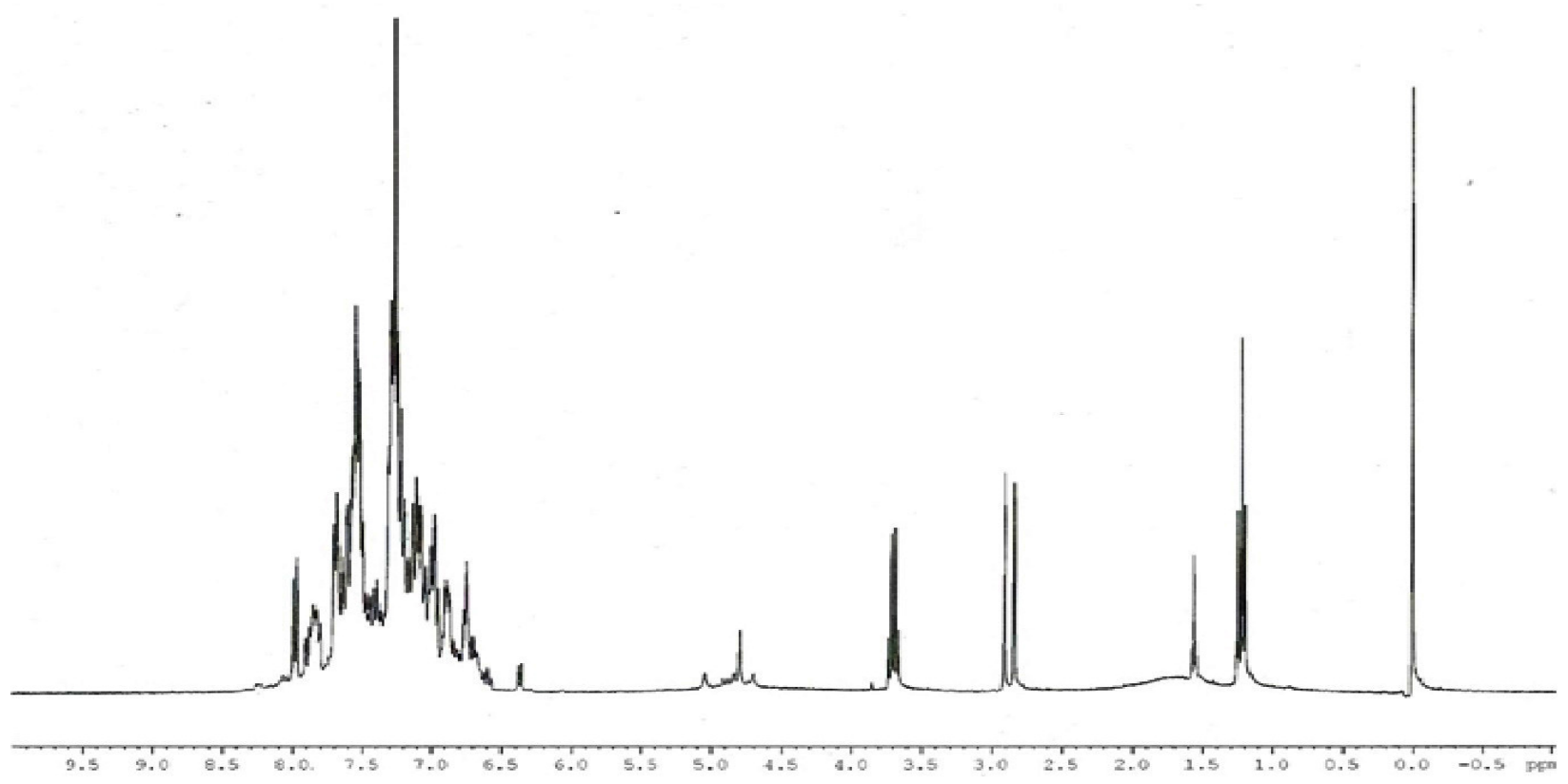

Fig.-3: $\mathrm{H}^{1}$-NMR spectrum of the ligand

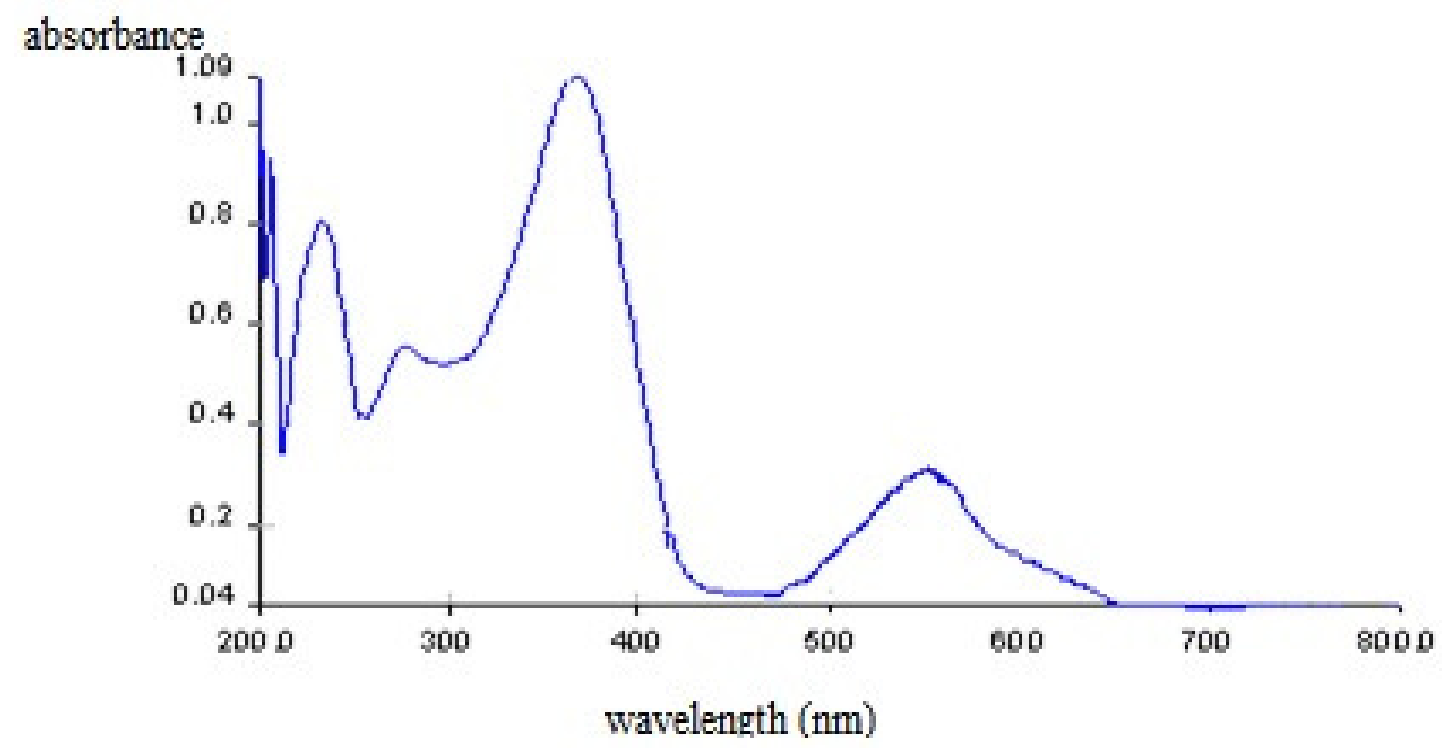

Fig.-4: Electronic spectrum of $\mathrm{Cu}(\mathrm{L})$ 
RASĀYAN J. Chem.

Vol. 11 | No. 2 |857- 864 | April - June | 2018

Table-1: Electronic absorption spectral data of ligand and its metal complexes.

\begin{tabular}{|c|c|c|c|c|c|}
\hline Compound & Complexes & Solvent & Absorption & Band Assignment & Geometry \\
\hline $\mathrm{L}$ & $\mathrm{C}_{14} \mathrm{H}_{11} \mathrm{NO}_{4}$ & $\mathrm{EtOH}$ & $\begin{array}{l}274 \\
315 \\
415\end{array}$ & $\begin{array}{l}\pi \rightarrow \pi^{*}- \\
\mathrm{n} \rightarrow \pi^{*} \\
\mathrm{~L} \rightarrow \mathrm{M}\end{array}$ & - \\
\hline $\mathrm{Cu}(\mathrm{L})$ & $\mathrm{C}_{28} \mathrm{H}_{20} \mathrm{~N}_{2} \mathrm{O}_{8} \mathrm{Cu}$ & DMF & $\begin{array}{l}256 \\
310 \\
413 \\
625 \\
\end{array}$ & $\begin{array}{l}\pi \rightarrow \pi^{*}- \\
\mathrm{n} \rightarrow \pi^{*} \\
\mathrm{~L} \rightarrow \mathrm{M} \\
{ }^{2} \mathrm{~B}_{1 \mathrm{~g}} \rightarrow{ }^{2} \mathrm{~A}_{1 \mathrm{~g}}\end{array}$ & Square planar \\
\hline $\mathrm{Ni}(\mathrm{L})$ & $\mathrm{C}_{28} \mathrm{H}_{20} \mathrm{~N}_{2} \mathrm{O}_{8} \mathrm{Ni}$ & DMF & $\begin{array}{l}287 \\
348 \\
469 \\
513,658\end{array}$ & $\begin{array}{l}\pi \rightarrow \pi^{*}- \\
\mathrm{n} \rightarrow \pi^{*} \\
\mathrm{~L} \rightarrow \mathrm{M} \\
{ }^{1} \mathrm{~A}_{1 \mathrm{~g}} \rightarrow{ }^{1} \mathrm{~A}_{2 \mathrm{~g}} \\
{ }^{1} \mathrm{~A}_{1 \mathrm{~g}} \rightarrow{ }^{1} \mathrm{~B}_{1 \mathrm{~g}}\end{array}$ & Square planar \\
\hline
\end{tabular}

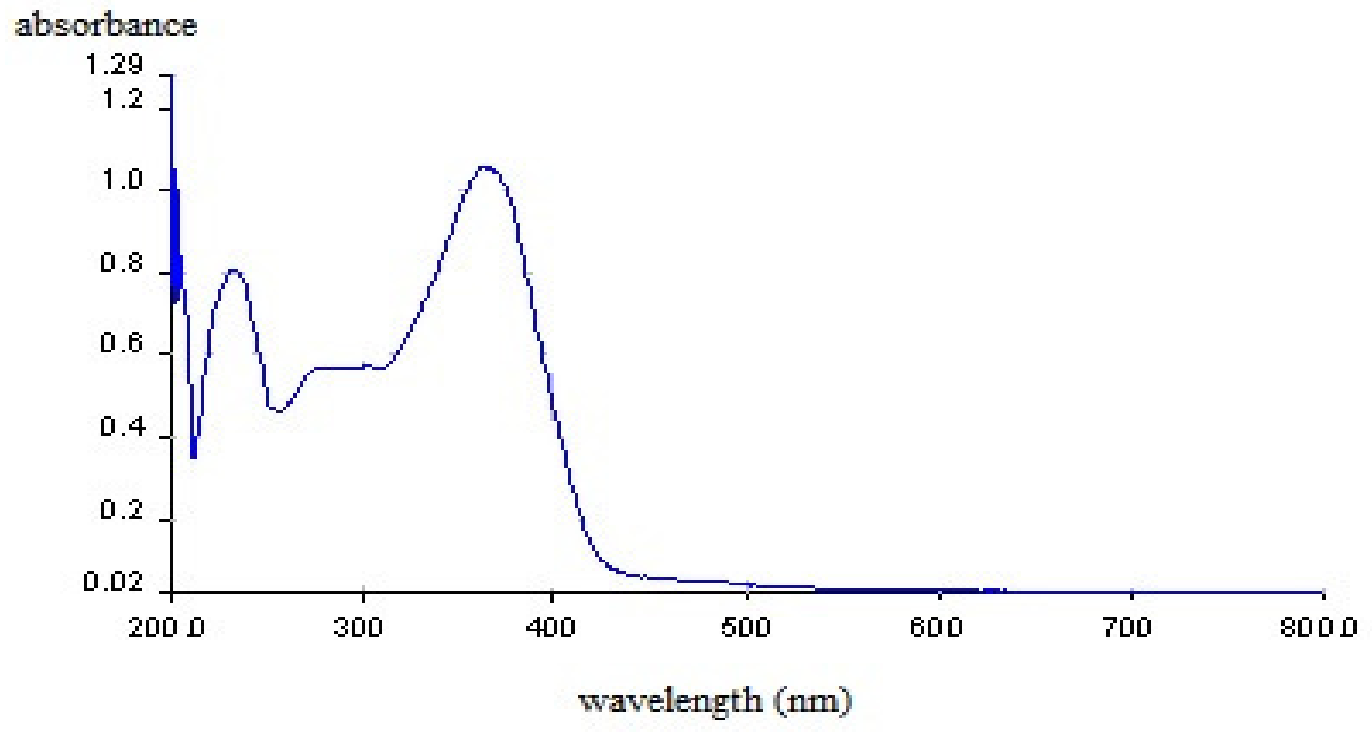

Fig.-5: Electronic spectrum of $\mathrm{Ni}(\mathrm{L})$

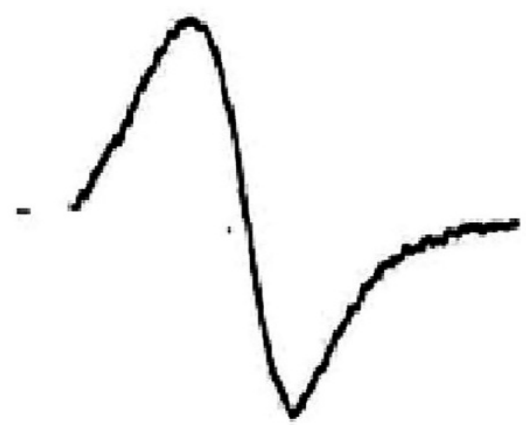

\section{Cyclic Voltametry}

Fig.-6: EPR Spectra of Cu(II) Schiff Base Metal Complex

Cyclic voltammogram of the $\mathrm{Cu}(\mathrm{II}), \mathrm{Ni}$ (II) complexes was recorded in aqueous solution with $\mathrm{NaClO}_{4}$ as the sustaining electrolyte. The voltammogram of the complex is shown in Fig. 7 . The cyclic voltammogram of the above complex showed two quasi - redox complex, shown in the Table-2. The electrochemical properties of the $\mathrm{Cu}(\mathrm{II})$ and $\mathrm{Ni}(\mathrm{II})$ complex exposed the quasi-reversible one electron transfer redox process. 


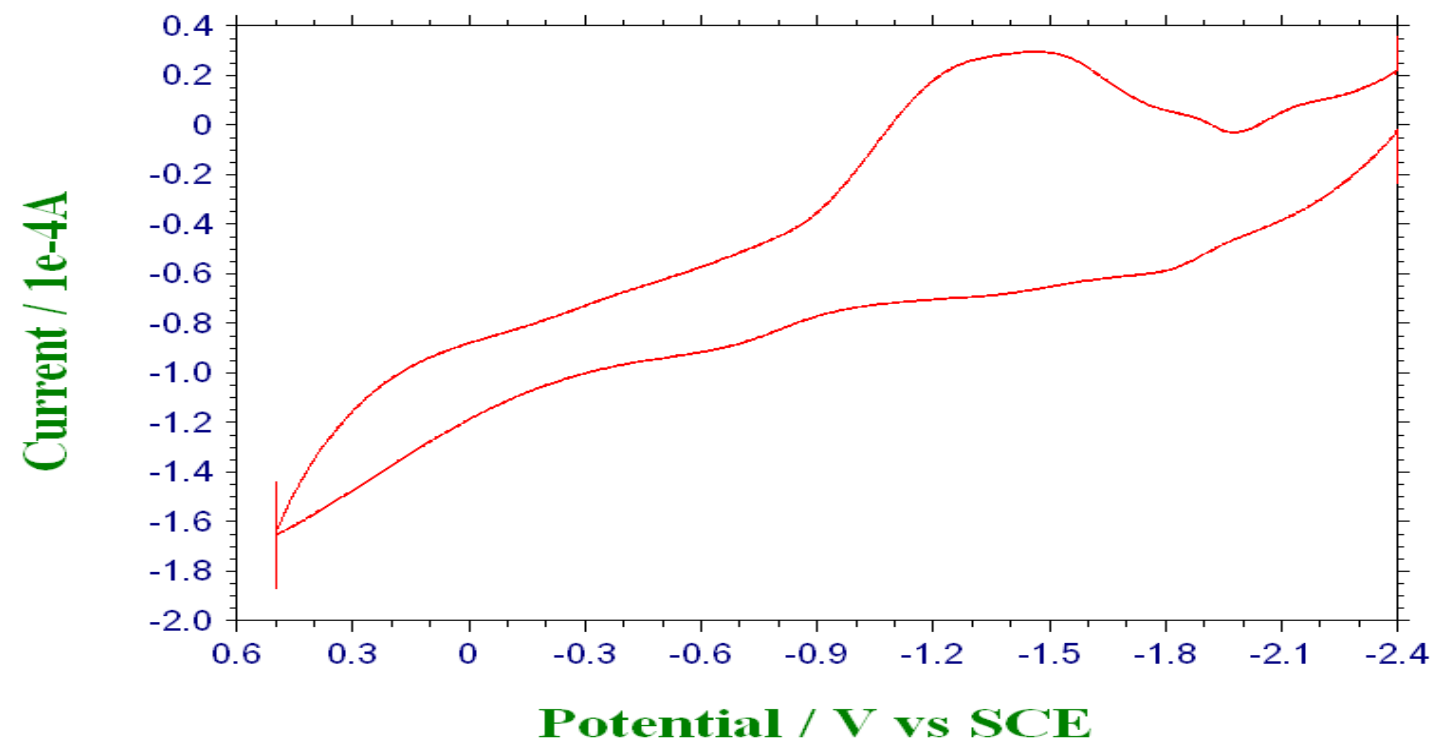

Fig.-7: Cyclic voltammogram of the $\mathrm{Cu}(\mathrm{L})$

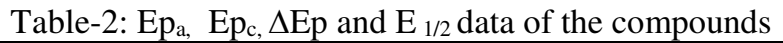

\begin{tabular}{c|c|c|c|c}
\hline Complex & $\operatorname{Ep}_{a}(\mathrm{~V})$ & $\operatorname{Ep}_{\mathrm{c}}(\mathrm{V})$ & $\Delta \mathrm{Ep}(\mathrm{V})$ & $\mathrm{E}_{1 / 2}(\mathrm{~V})$ \\
\hline \multirow{2}{*}{$\mathrm{Cu}(\mathrm{II})$ complex } & 0.24 & 0.12 & 0.12 & 0.18 \\
\cline { 2 - 5 } & -1.3 & -1.8 & -0.5 & -1.55 \\
\hline \multirow{2}{*}{$\mathrm{Ni}(\mathrm{II})$ complex } & 0.45 & 0.23 & 0.22 & 0.34 \\
\cline { 2 - 5 } & -1.32 & -1.84 & -0.52 & -1.58 \\
\hline
\end{tabular}

\section{Thermo Gravimetric Analysis}

The energetic TGA with the percentage mass loss at dissimilar steps has been recorded. The thermal decay of the $\mathrm{Cu}$ (II) complex with molecular formula [ $\mathrm{CuC}_{28} \mathrm{H}_{20} \mathrm{~N}_{2} \mathrm{O}_{8}$ ] proceeded with only one main degradation step is shown in Fig.-8. The first step took place within the temperature range $180-652^{\circ} \mathrm{C}$ with an expected mass loss of $43.72 \%$ [calculated mass loss $=44.61 \%$ ], which is practically accounted for the loss of aromatic ligand group and an amine group. In the temperature range $300-600^{\circ} \mathrm{C}$, the mass loss was in advancement. The result of the thermal analysis showed good concord with the theoretical formula recommended from the elemental analysis ${ }^{15-16}$.

\section{DNA Cleavage Studies}

The cleavage effectiveness of the complexes to that of the control was due to their capable DNA-binding ability. The metal complex was intelligent to convert super coiled DNA (Form- I) into open circular DNA (Form -II).The general oxidative mechanism proposed report of DNA cleavage by hydroxyl radicals via, abstraction of a hydrogen atom from sugar units and forecast the release of precise residue arising from transformed sugars, depending on the location from which the hydrogen atom is detached ${ }^{17}$. The cleavage was repressed by the free radical scavengers implying that hydroxyl radicals or peroxy derivatives restrained the cleavage reaction. The reaction was modulated by a metallo complex bound hydroxyl radical or peroxo species generated from the co-reactant $\mathrm{H}_{2} \mathrm{O}_{2}$.In the present study, the CT - DNA gel electrophoresis experiment was conducted at $35^{\circ} \mathrm{C}$ by the synthesized complex in the occurrence of $\mathrm{H}_{2} \mathrm{O}_{2}$ as an oxidant. As can be seen from the results in figure 9, at very low concentration, Nickel complex exhibits nucleus movement in the presence of $\mathrm{H}_{2} \mathrm{O}_{2}$. Control experiments using DNA alone do not show any major cleavage of CT -DNA even no longer disclosure time. From the observed results, it is 
calculated, that the nickel complex cleaves DNA as compared to control DNA. Further, the presence of a smear in the gel diagram indicates the presence of radical cleavage ${ }^{18}$.

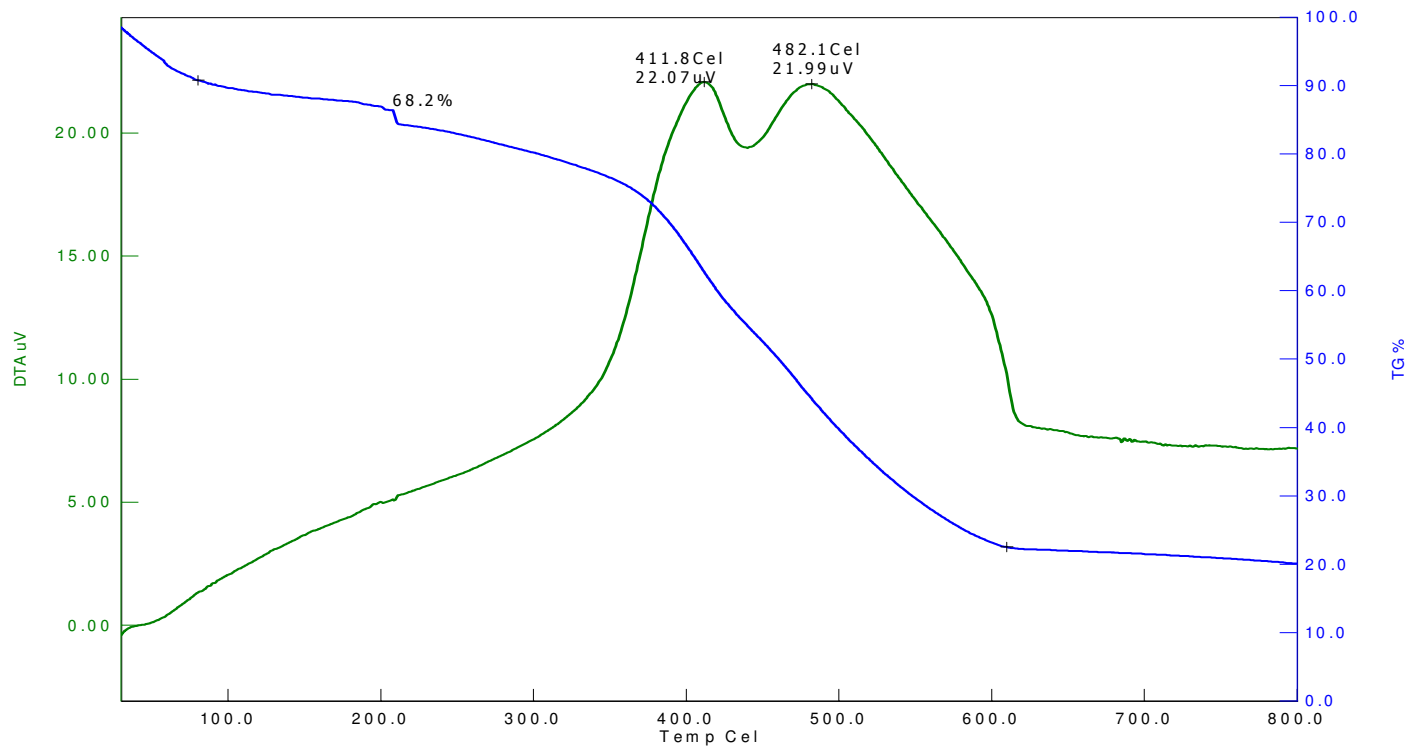

Fig.-8: Thermal Analysis of $\mathrm{Cu}(\mathrm{L})$

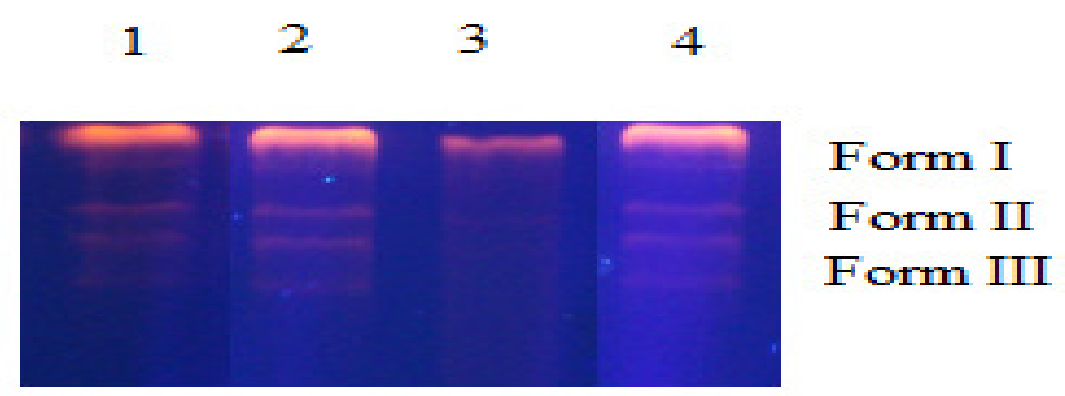

Fig.-9: DNA Cleavage studies of Ni(L) Schiff base metal complexes.

Lane 1 - DNA alone, Lane 2 - DNA + Ni(II) complex

Lane 3 - Ni (II) complex $+\mathrm{H}_{2} \mathrm{O}_{2}$, Lane 4 - DNA + Ni(II) complex $+\mathrm{H}_{2} \mathrm{O}_{2}$

\section{Antimicrobial Assay}

Antimicrobial activity of the ligand and its complexes have been carried out against staphtylococcus, Bacillus sp, E.coli and pseudomonas by well - diffusion method using DMF as solvent as shown in Table-3.The cram of MIC values of the Schiff base and its complexes designate that the metal complexes showed the evidence of higher antibacterial activity than that of the free ligands. This was most likely due to the superior lipophilic nature of the complexes such as enlarged activity of the metal chelates can be explained on the basis of overtones concept and chelation theory. According to overtone's concept of cell permeability the lipid membrane that ambiance the cell favored the passage of only lipid soluble material due to which liposolubility is an important reason which controls the antimicrobial activity. On chelation, the polarity of the metal ion will be condensed to a better extent due to the overlap of the ligand orbital and partial sharing of positive charge of the metal ion with donor groups. Further, it increased the delocalization of $\pi$-electrons over the whole chelate ring and enhances the lipophilicity of the complex. 
The increased lipophilicity enhanced the incursion of the complexes into lipid membrane ${ }^{17}$ and blocked the metal binding sites on enzymes of microorganisms. Schiff base compounds have been shown to be hopeful leads for the intend of more proficient antimicrobial agents.

Table-3: Antibacterial activity of the Schiff base metal complexes

\begin{tabular}{c|c|c|c|c}
\hline Compounds & $\begin{array}{c}\text { E.Coli } \\
(\mathrm{mm})\end{array}$ & $\begin{array}{c}\text { Bacillus sp } \\
(\mathrm{mm})\end{array}$ & $\begin{array}{c}\text { Pseudomonas } \\
(\mathrm{mm})\end{array}$ & Staphylococcus (mm) \\
\hline $\mathrm{L}^{6}$ & 5 & 3 & 6 & 5 \\
\hline $\mathrm{Cu}\left(\mathrm{L}^{6}\right)$ & 17 & 16 & 19 & 18 \\
\hline $\mathrm{Zn}\left(\mathrm{L}^{6}\right)$ & 13 & 12 & 13 & 14 \\
\hline $\mathrm{Ni}\left(\mathrm{L}^{6}\right)$ & 10 & 9 & 8 & 12 \\
\hline
\end{tabular}

\section{CONCLUSION}

The monodentate Schiff base ligands have been prepared and were engaged to synthesize a novel sequence of $\mathrm{Cu}$ (II) and $\mathrm{Ni}$ (II) complexes. The spectral results propose the existence of square planar geometry for $\mathrm{Cu}$ (II) and Ni (II) complexes. The molar conductance measurements of the complexes showed their non - electrolytic nature. Further, these complexes were screened for antimicrobial activity and the results suggest that mixed ligand complexes have advanced antibacterial activity than the free ligand. Schiff bases are very imperative in medicinal and pharmaceutical fields. Gel electrophoresis experiment suggests that all the transition metal complexes have activity than the control CT - DNA.

\section{REFERENCES}

1. Y. Ibrahim and C. Alaaddin, Trans. Met. Chem., 28, 399 (2003).

2. G. Deltor, F. Binon, F. Henaux and R.Charlier, Arch Itern Pharmacrodynamic, 131, 84 (1961).

3. D. R. Sridhar, C. V. R. Sastry, K. B. Lal, O. P. Bansal and S. M. Sondhi , J. Indian Chem. Soc., 55, 910 (1978).

4. A. C. Hiremath, M. B. Halli, N. V. Huggi and S. M. Gaddad, Indian J. Microbiol., 29, 73 (1989)

5. L. I. Smith and J. W. Opie, Org. Synthesis Coll., 28, 11 (1948), DOI: 10.1016/00221902(79)80376-0.

6. M. M. El-Ajaility, A.A. Maihub, S. S. Hurdere and S. M. Ben Saber, Asain J. Chem.,(2006).

7. D. P. Singh, Vandna Malik, Ramesh Kumar and Krishnan Kumar, Rasayan J. Chem., 2,133 (2009).

8. R. Bu Xiu, E. A. Mintz and X. Z. You, Polyhedron, 15, 4585 (1996), DOI: 10.1023/B:TMCH.0000019409.50574.0a

9. A. B. P. Lever, Inorganic Electronic Spectroscopy. 1st ed., Amsterdam Elsevier, p. 249- 360(1968), DOI: $10.1002 /$ bbpc. 19850890122

10. L. N. Sharadha and M. C. Ganorkar, Indian J. Chem., 27A, 617(1988), DOI: 10.1016/j.saa.2013.04.054.

11. D. U. Warad, C. D. Satish, V. H. Kulkarni and C. S. Bajgur, Ind. J. Chem., 39A, 415 (2000), DOI: 10.1016/j.arabjc.2012.04.048.

12. N. Raman, S. J. Raja, J. Joseph and A. Sakthivel, Russ. J. Coord. Chem., 34, 842(2008).

13. N. Raman and S. Sobha, J. Serb. Chem. Soc., 75, 773 (2010).

14. K. Nakamoto, Infrared spectra of Inorganic Electronic Spectroscopy, Ist ed., Elsevier, Amsterdam,(1968).

15. D. C. Dash, F. M. Meher, P. C. Mohanty and J. Nanda, Indian J. Chem., 26(A), 698 (1987).

16. J. T. Makode and A. S. Aswar , Indian J. Chem., 43(A), 2120(2004), DOI: 10.1155/2013/479343

17. G. Prativel, M. Pitie, J. Bernadou and B. Meunier Angew, Chem. Int. Ed. Eng, 30, 702 (1991).

18. N. Dharmaraj, P. Viswanamurthi and K. Natarajan, Transition Met. Chem., 26, 105 (2001).

[RJC-3033/2018] 